\title{
Determinants of household residential location choice among informal settlers in Port Harcourt
}

\begin{abstract}
Informal settlements, sometimes called slums, are sites of significant environmental risk in developing cities. Despite its environmental challenges, residents prefer to live in informal settlements rather than planned allocated plots. This paper assesses the determinants of households' residential location decision in an informal settlement in Port Harcourt in order to gain understanding on what makes individuals consider a particular location in an informal settlement. The study employs a case study approach and uses both indepth faceto-face interviews and structured questionnaires on waterfront households using Cluster sampling to group the settlements into seven (7) zones based on their location in order to capture information on residential location choice decisions of respondents in the informal settlements. In each settlement, we interviewed two households, thereafter questionnaires were administered on 55 respondents' household by trained graduate students who worked as enumerators. In all a total of 14 interviews were conducted and 385 questionnaires administered. Out of the 385 questionnaires administered, 315 were completed and returned. The results of the survey corroborated by an indebth interview revealed that the growing informality are not limited to income level, but household uses social networks (living close to family or friends), livelihood opportunities, proximity to work, and commuting cost to find accommodation, land for building and support for everyday life in an informal settlement.
\end{abstract}

Keywords: household, determinants, informal settlement, residential location, residential choice
Volume 6 Issue 3 - 202I

\author{
Deeyah Christopher L,' Ohochuku \\ Chinwennwo P, ${ }^{2}$ Eke Stanley $\mathrm{N}^{3}$ \\ 'Department of Estate Management, Faculty of Environmental \\ Sciences, Rivers State University, Nigeria \\ ${ }^{2}$ Department of Architecture, Faculty of Environmental Sciences, \\ Rivers State University, Nigeria \\ ${ }^{3}$ Department of Surveying and Geo-informatics, Faculty of \\ Environmental Sciences, Rivers State University, Nigeria
}

\section{Correspondence: Deeyah, Christopher Ledor, Department of Estate Management, Faculty of Environmental Sciences, Rivers State University, Port Harcourt, Nigeria, Email chrisdeeyah@gmail.com}

Received: June 13, 2021 | Published: June 24, 202 I

\section{Introduction}

Over the past few decades, urban communities have become the central hub for human existence. People prefer to live in urban areas instead of rural communities. An estimation made by the ${ }^{1}$ suggests that about $70 \%$ of the world's population will live in urban centres by 2050. Even before 2050, the world should expect more than $60 \%$ of its population living in urban areas by 2030 , with Africa recording a rapid rate of urbanisation..$^{2,3}$ The unprecedented growth of cities has led to an increase in risk to disasters and global climate change, as an ever greater share of the population and built environment is concentrated in areas exposed to environmental hazards like floods, storms, and landslides. ${ }^{4}$ The rising spate of urban share of population has led to the development and continual expansion of informal settlements and slums.

The growth of informal residential areas implies that people are moving to them occupying geographic space and consequently changing the use of land. ${ }^{5}$ Adds that the informal sector has since the early days of independence been the dominant provider of urban land and housing, as only about $20 \%$ to $40 \%$ of the physical development in Nigerian cities is carried out with formal government approval. ${ }^{6}$ Attributed this trend to the weakness of government planning controls, and the haphazard development associated with the informal sector. ${ }^{6}$ Citing Leduka (2000) also attributed the growth of informal settlements to the difficulty of obtaining land and housing through established legal or formal processes. Thus, the development of informal settlements involves not only the urban poor but also the urban wealthy political leaders and state bureaucrats.

In Port Harcourt, despite many government attempts to facilitate affordable land and housing for the rapidly growing urban population, it cannot keep pace. As a result the informal housing development processes continue to provide a haven for housing and livelihoods for urban residents. Informal settlements in Port Harcourt are direct manifestation of poor urban management and failure of government planning response to urban growth. The public sector capacity to provide services and manage urban development has also diminished. ${ }^{6}$ Observed that formal planning is facing a problem of legitimacy in Rivers State in the absence of a proper institutional framework and enabling legislation; hence much of urban growth in Port Harcourt in post-independence times has occurred outside the control of state laws and regulatory frameworks.

Informal settlements, sometimes called slums, are sites of significant environmental risk in developing cities. Informal settlements are communities where residents, often poor, have inadequate access to water, sanitation, and other basic infrastructure and services, live in crowded and poorly constructed housing, and/ or have insecure tenure, ${ }^{7,8}$ Despite this institutional weaknesses and urban poverty related reasons; the proliferation of informal housing has also been attributed to the question of 'location'. ' According to, ${ }^{9}$ residents preferred to live in informal settlements rather than planned allocated plots, which were far from jobs. A Study by ${ }^{10}$ on livelihoods in other developing countries indicates that households generally require locations that facilitate access to employment opportunities, services and public amenities. The author further emphasise that, access to secure land and shelter in good locations is a precondition for survival and success of households in the urban areas.

Decisions on choice of residential location are made within the context of households whose primary objective is to provide shelter. Many studies on household residential location choice have suggested wide ranging explanations on the determinants for residents' location choice particularly accessibility and transportation possibilities, amenities, facilities and features of the residential environment, 
attachment to the neighborhood and social, economical and demographical character of the individuals in the house. For example, ${ }^{11}$ shows that residential location decision is influenced by four major factors, namely: residential environment, availability of amenities and opportunities, traffic and accessibility as well as frequent destinations, which is pedestrian and public transport accessibility to addresses. ${ }^{12}$ Established that travel time and travel cost are significant factors in residential location while population density has a weak influence on residential influence in Manila. While, ${ }^{13}$ revealed that quiet, safety and low traffic volume are key factors urban dwellers in Brussels consider in the choice of residential location. ${ }^{14}$ Also established that house characteristics, travel time, ease of access and public transport system contribute significantly to the location decision of residence.

A common feature shown by these studies is the fact that Location decision is not a standard behaviour governed by absolute rules. While some studies have emphasized each of these factors, others have focused only on a smaller subset. In spite of the considerable volume of literature on residential location choice, little research has been done specifically on developing countries such as Nigeria, especially amongst informal settlers hence the need for a study to fill this knowledge gap.

The focus of this study is to explain the residential location choices of residents in Port Harcourt in the context of informal settlements. Using watersides settlements in Port Harcourt as a case study, this study will assess the determinants of households' residential location decision, in order to gain understanding on what makes individuals consider particular locations in an informal settlements.

The paper is structured as follows: first, the introduction and extant literature on Informal settlement, Concept of residential location choice, and Determinants of Household Residential Location Choice are reviewed. This is followed by a description of the study area, research methods adopted for the study. The results of the study are then presented and discussed. Finally, conclusion and recommendation of the research are offered.

\section{Literature review}

\section{Informal settlement}

Informal settlements, sometimes called slums, are sites of significant environmental risk in developing cities. Informal settlements are communities where residents, often poor, have inadequate access to water, sanitation, and other basic infrastructure and services, live in crowded and poorly constructed housing, and/ or have insecure tenure. ${ }^{7,8}$ The term informal settlement implies the occupation and development of land at fairly high densities, which has been developed outside the planning machinery. ${ }^{9}$ The development can be through the 'illegal' sub-division of land or through organised invasion by people, of the land. Due to the 'illegal' status, social and infrastructure services are usually inadequate or completely lacking. ${ }^{15,9}$ The proliferation of informal housing has also been attributed to the question of 'location'. ${ }^{9}$ According to, ${ }^{9}$ residents preferred to live in informal settlements rather than planned allocated plots, which were far from jobs. Studies in other developing countries on livelihoods indicate that households generally require locations that facilitate access to employment opportunities, services and public amenities. ${ }^{10}$

Informal settlements (slums and squatter settlements) are the most tangible evidence of pervasive urban poverty, and in Nigerian cities; they range from clusters of shacks in environmentally fragile land areas to entire local government areas. As described by, ${ }^{16}$ while their physical forms vary by place and over time, slums are uniformly characterized by inadequate provision of basic infrastructure and public services necessary to sustain health, such as water, sanitation, and drainage. Port Harcourt is the largest and most significant urban centre in the Nigeria's Niger Delta with a population that has grown from 135,000 in 1960 to 1.47 million in 2010 and projected to reach 2.6 million in $2025 .{ }^{17}$ Recognized for its beauty and cleanliness, ${ }^{18}$ the erstwhile beautiful Garden City has now been taken over by as many as 49 recognized informal settlements ${ }^{19}$ accounting for $65 \%$ of the city's population..$^{20}$ Most of these settlements are located along the many water bodies that traverse the city. ${ }^{21}$

${ }^{13}$ Reported that One-third of the urban population in developing countries currently lives in informal settlements, ${ }^{13}$ totalling 863 million people; while ${ }^{22}$ notes that this number may triple by 2050 . With the tremendous growth in the number, size, and population of informal settlements will come a precipitous increase in disaster risk. ${ }^{23}$ Port Harcourt, like other fast growing cities of the third world, has its many low income informal settlements. These are located on the waterfronts of the city and are locally called "watersides".

\section{Concept of residential location choice}

Residential location refers to the exact house or apartment that a household chooses. ${ }^{24}$ Residential choice which is defined as the choice of the place where households live, and when it is dissatisfied with its current home, decide when and where to move to, is a fairly complex issue. ${ }^{25}$ According to Giuliani, ${ }^{26}$ residential choice involves an assessment wherein the desires of an ideal environment are evaluated and used to make a choice among alternatives. Growing numbers of urban dwellers are confronted with deciding on the most suitable location to reside. Consequently, the process of moving to a new residential area is an important decision in the lives of households. Households choice of residence generally involves trade-offs between several factors which maximise the utility of the households. Numerous decisions including constraints such as access to facilities and travel time to various locations, among others, are considered and made. These decisions are made within a rapidly urbanising society, a situation which leaves most households with the hardest of life choices.

\section{Determinants of household residential location choice}

Literature suggests that household location decisions are not influenced by any one particular factor or local services. A range of factors come into play when households choose where to live or where they live. Most studies on residential location choice in the relevant literature are interested with the accessibility and transportation possibilities, amenities, facilities and features of the residential environment, attachment to the neighbourhood and social, economical and demographical character of the individuals in the house.

Studies have shown that proximity to the city center or workplace together with the quality and diversity of transportation facilities in residential environment appear to be the most important factors in residents' location choice. Households and individuals locate themselves based on their travel preferences. A study of Residential Location Preferences by, ${ }^{27}$ found that access to public transport, ease of cycling or walking, low levels of car traffic, and pedestrian friendliness are residential preference factors categorized as travel behaviour and pro public transport. ${ }^{28}$ Found that safety and proximity to the city, public transportation, proximity to workplace, sense of safety, medical and health facilities, and educational facilities influence residence location choice. 
The results of studies which explore the role of transport factors in the residential location of households have been mixed. While some researchers find that transport factors to play an important role in household residential location, others contend that the high level of accessibility afforded by private cars nearly everywhere in metropolitan areas diminishes the importance of transport factors. In a study of commuting behaviour and residential location in Los Angeles, US, ${ }^{29}$ found that households generally commute more than they need to and this suggests that transport, to the workplace at least, is not a salient determinant of residential location. On the other hand, a more recent stated preference experiment exploring residential location choice behaviour in Oxfordshire, UK, found that transport factors were important determinants of housing movement and location choice. The study found that an increase in travel time or cost to work or shopping was a good predictor of household movement (i.e. a 'push factor'). The authors concluded that "individuals prefer residential locations with a combination of shorter commuting time, lower transport costs, lower density and higher school quality". ${ }^{30}$

Another major determinant of residential location preference is demographic structure. ${ }^{31}$ Stage of family or household cycle is a major consideration in the choice of where to live. ${ }^{32}$ Argued that the residential mobility of elderly is lower than that of the younger age groups. Income is another factor that affects preference on where to live. On housing decisions, this factor has been of considerable interest among researchers. ${ }^{33}$ Are of the view that income affects housing affordability but weaker relationship exists between income and housing price. Their conclusion is that there is no income elasticity for housing.

In their UrbanSim model,${ }^{34}$ have found that different income and age groups have divergent preferences regarding residential location factors. They also emphasize that residential segregation by income exists in the Korean case. ${ }^{35}$ Survey shows that residential preference varies according to personal choices, family size, and income level. ${ }^{36}$ Suggested that households with higher incomes, children, or two workers demonstrate different housing consumption patterns.

Studies found social relation and prestige is an important determinant of household residential location. Social networks and social relations have been suggested as indicators of social capital that play an important role for urban residents coping with life in urban areas. In the urban livelihoods' framework, social capital refers to networks of mutual support that exist within and between households, extended family, and communities, which people can mobilise to access accommodation and information about employment and opportunities. ${ }^{37}$ Although not as generalizable as other factors, social relations can be an important guide in the housing location choice of minority groups in a city. ${ }^{38}$ Showed that in United State "households tend to locate in an area with a high proportion of other households with a similar household structure and household size as their own. ${ }^{27}$ Also explained that car ownership makes distance much less of a factor in the choice of residential location. For individuals, a feeling of belonging to their environment has a crucial effect on satisfaction. Close proximity to family, friends, relatives, or social groups and to neighbours of like mind and social status is important in choices concerning residential location..$^{39}$ addressed the issue as "social space" and emphasized the importance of the breadth of social networks in the choice of housing environment. Social relations, expressed as "community preferences" in the ${ }^{35}$ are given as one of the factors that govern residential preference, although they are found to be relatively less important than other factors. In a study on exploring residential mobility, ${ }^{40}$ showed that familiarity and social connections influences residential location choice. They claimed that many people are reluctant to leave familiar and convenient surrounding to which they have grown accustomed and became attached. As most households make housing choices within budgetary constraints, housing cost is a significant factor in household location choices. A major Australian study found housing affordability to be an important determinant of household residential location which, combined with a desire to achieve home ownership, is one of the reasons that households have moved to the urban fringe. ${ }^{41}$

African scholars have also investigated the theory surrounding Residential Location Choices. In Ghana, a study by ${ }^{42}$ notes that family relations, proximity to workplace, relatively low land price and house rentals are the most important explanatory variables for RLC in two of Kumasi's peri-urban settlements. The study suggests that socio-cultural, dwelling and accessibility considerations are significantly more important than the housing attributes related to the neighbourhood. Similarly, the findings of ${ }^{43}$ reflected on the role of socio-cultural cohesion and accessibility as the most prominent determinants of household choice of residential location in Benin City, Nigeria.

Concern for household residential location choice is not in any way just a local phenomenon. Several studies have been carried out in regard to household residential location choice in both developed and developing countries. Notably, these researches have not focused on informal settlement hence the rationale behind the current study.

\section{The study area}

Port Harcourt is the capital city of Rivers state, the administrative headquarter of the oil rich Niger Delta of Nigeria is one of the nation's fastest growing cities. It was established in 1913 because its site met the location requirement set by the Nigeria Colonial Surveyors for a Port - terminus deep water near ground which shall be connected to the mainland. ${ }^{44}$ Port Harcourt is situated within latitudes 040 $43^{\text {ee }}$ and $04057^{\text {ee }}$ North of the Equator and between longitudes 060 $53^{\mathrm{ee}}$ and $07058^{\mathrm{ee}}$ East of the Greenwich Meridian. It is surrounded by patches of islands and creeks of the Niger Delta, such as the Dockyard creek, Bonny River and Amadi creek, at a height of about $12 \mathrm{~m}$ above sea level. ${ }^{45}$ It is approximately $60 \mathrm{~km}$ from the crest up stream of the Bonny River. The Port Harcourt metropolitan city presently comprised two local government areas - Obio/Akpor and Port Harcourt City Local Government Council areas (LGAs). Informal settlements in Port Harcourt are located on the waterfronts of the city and are locally called "watersides". Waterfront settlement, also called waterside started as informal settlements where farmers and fishermen who brought in food and fish from the hinterland and riverine communities to Port Harcourt to sell, made their temporary homes during their trips. ${ }^{46}$ Waterfront settlements were not popular in the city of Port Harcourt until after the civil war. ${ }^{47}$ Reported that the economic viability of the new Rivers State capital coupled with its advantageous geographical location made it a haven for people from different parts of the country in the early 70's. By the end of the 70's competing land uses and struggles for space in the city has over stretched the available land space leading to adverse pressure on the existing residential accommodation. The author notes that the inability of the available housing stock to meet up with demand lead to "housing famine" in the city and consequently high cost of residential accommodation. Household who could not afford the high rent especially the low income begin to look at land at the "Waterside" of the city as an alternative where land was less desirable, the government and private home developers were not interested. Despite 
the difficult geographical terrain of the place; susceptible to flooding, Waterside settlement as they are popularly called has become a part and parcel of the oil rich city of Port Harcourt. Today there are thirty major identifiable "waterside" settlements in the city.). ${ }^{19,48}$ put the total number of waterfront settlements in Port Harcourt to be Forty-nine
(49) and estimated the population of the waterfronts to account for about $65 \%$ of the city's population. On his part ${ }^{47}$ put the total number of waterfronts settlements at thirty-two..$^{49}$ estimate the population of the waterfronts settlers to be between 200,000 and 500, 000 (Figure 1) (Figure 2).

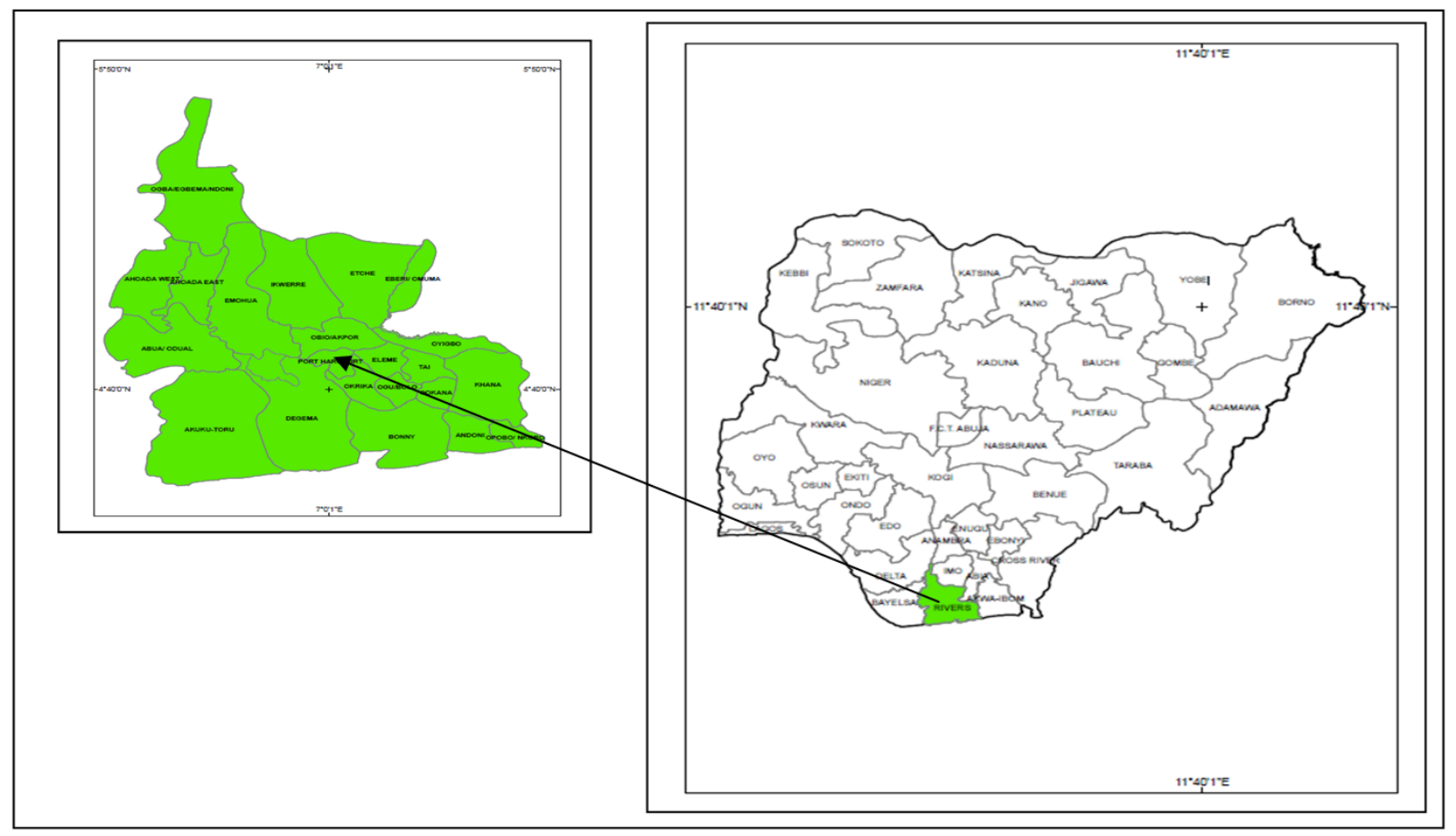

Figure I Map of Nigeria showing rivers state and Port Harcourt local government area.

Source: Geomatics Department, SPDC, Port Harcourt.

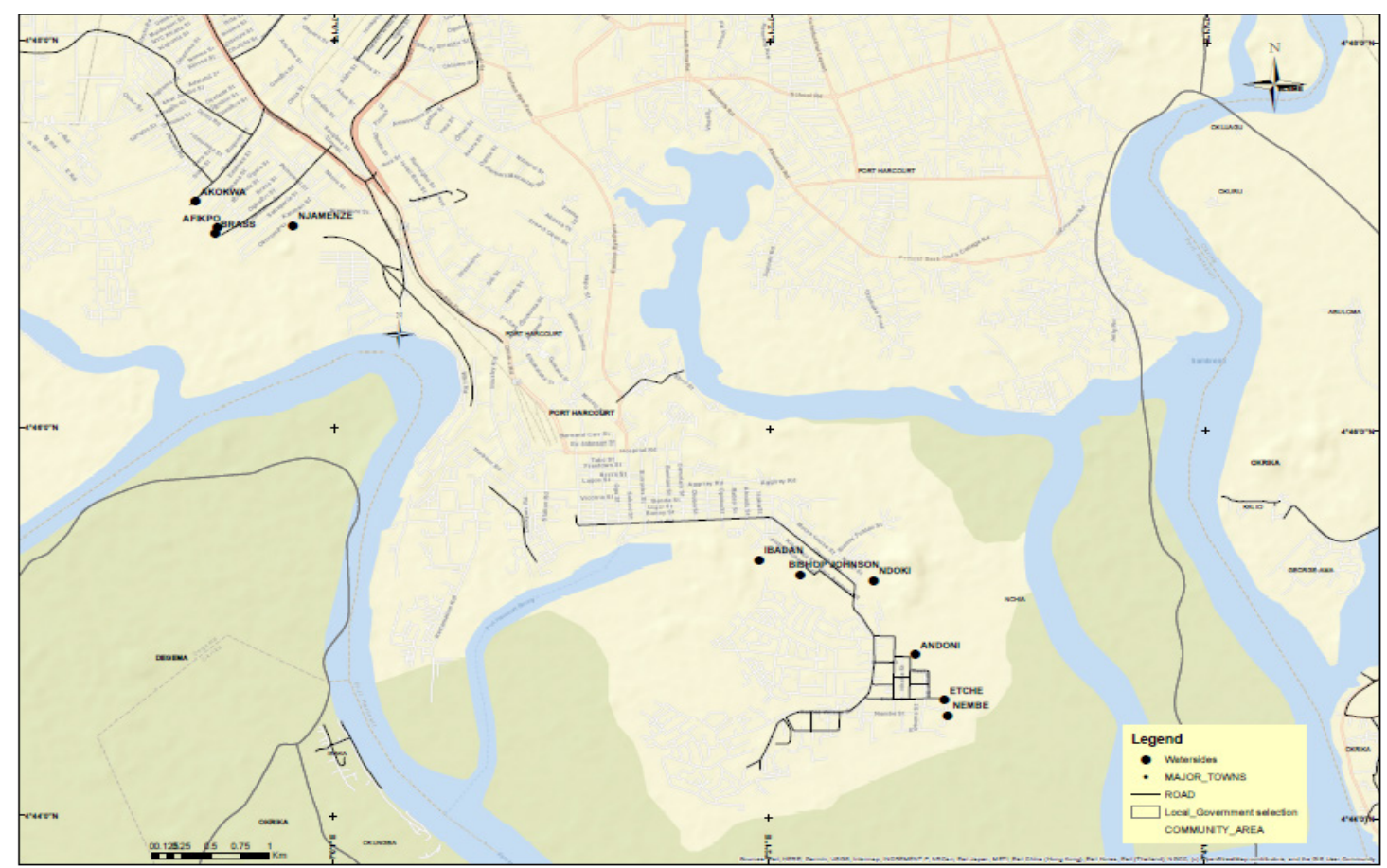

Figure 2 Map showing selected informal (waterside) settlement in Port Harcourt, rivers state.

Source: Geomatics Department, SPDC, Port Harcourt. 


\section{Research methodology}

The case study design was chosen for this research in order to maximise the chances of realizing the research objectives. According to ${ }^{50}$ case study investigates a contemporary phenomenon within its reallife context and addresses situations in which the boundaries between phenomenon and the context are not clearly evident using multiple sources of evidence. One of its strength is the use of triangulation. Triangulation uses evidence from different sources to corroborate the same fact or finding. Triangulation is an approach that combines both quantitative and qualitative forms within a study. ${ }^{51}$ Triangulation is described in social science as "the mixing of data or methods so that diverse viewpoints or standpoints cast light upon a topic". ${ }^{22}$ Srgues that one reason why researchers adopt triangulation is to enhance confidence in the ensuing findings, and that triangulation is more related with occasions where researchers seek to check the validity of their findings by cross-checking them with another method..$^{53}$

The data for this study was collected primarily using both interview and structured questionnaires on waterfront households using Cluster sampling to group the settlements into seven (7) zones based on their location while Seven (7) waterfront settlements were randomly selected. The waterfront settlements selected are Akokwa, Afikpo, Ibadan, Bishop Johnson, Ndoki, Etche, and Andoni which are on the northern parts of Port Harcourt. The target population (resident household heads) comprised both tenants and landlords who live in the informal settlements (watersides) in Port Harcourt. In each settlement, we interview two households, thereafter questionnaires was administered on 55 respondents' household by trained graduate students who worked as enumerators. In all a total of 14 interviews were conducted and 385 questionnaires administered. Out of the 385 questionnaires administered, 315 were completed and returned representing $81.9 \%$ and were found adequate for the research.

The data from the questionnaire survey was analysed and presented using percentages, mean and Relative Significance Index (RSI) while the interviews were analysed and presented using narration and direct quotes from respondents.

\section{Results and discussion}

This section of the paper presents the findings and discussion of the data collected from the field survey. Data on the demographic and socio-economic characteristic of the respondents is presented and discussed. Several factors such as livelihood opportunities, low rents and low costs of living, living close to family or friends, nearness to children school, Employment availability, availability of health facilities, Proximity to work, natural features, commuting cost, personal reason, neighbourhood character, nearness to market, street cleanliness are analysed as they influence household residential location decision in an informal settlement.

\section{Socio-economic characteristics of households of sampled respondents}

Table 1 provides a socio-economic profile of respondents who participated in the study. The respondents were household heads and were dominated by male respondents with $(82.86 \%)$ and approximately, $89.20 \%$ of the respondents had at least some formal education, with $40.00 \%$ having earned a tertiary degree. This suggests that many informal settlers only possess basic primary and secondary education. Many of the respondents in waterfronts settlement were engaged in work that did not require a high educational background such as fishing, petty trading, tailoring and hair plaiting, however results shows that only a small percentage of the respondents are employed.

Table I Socio-economic characteristics of households of sampled respondents

\begin{tabular}{lll}
\hline Variables & Frequency & Percentage \\
\hline Gender & & \\
Male & 261 & $82.86 \%$ \\
Female & 54 & $17.14 \%$ \\
Total & 315 & $100 \%$
\end{tabular}

Educational level of household head

$\begin{array}{lcc}\text { Never } & 34 & 10.80 \% \\ \text { Primary } & 58 & 18.41 \% \\ \text { Secondary } & 97 & 30.79 \% \\ \text { Tertiary } & 126 & 40.00 \% \\ \text { Total } & 315 & 100 \%\end{array}$

Employment status of household head

$\begin{array}{lcc}\text { Employed } & 75 & 23.81 \% \\ \text { Self employed } & 147 & 46.67 \% \\ \text { Unemployed } & 54 & 17.14 \% \\ \text { Retired } & 39 & 12.38 \% \\ \text { Total } & 315 & 100 \%\end{array}$

Monthly Disposal Household Income

$\begin{array}{lcc}\text { Below } 30000 & 87 & 27.62 \% \\ 30000-100,000 & 143 & 45.40 \% \\ \text { Over } 100,000 & 85 & 26.98 \% \\ \text { Total } & 315 & 100 \%\end{array}$

Source: Researcher's Field Survey, 2021

The responses also showed that $23.81 \%$ household are Employed, $46.67 \%$ are self employed only $17.14 \%$ remain unemployed while $12.38 \%$ are retired. On monthly Disposal Household Income, 27.62\% earn below N30000 while 45.40\% earn between N30000-N100,000. However, most of the household interviewed could not state their income with precision because they barely save. Our interactions confirm that their daily earnings were mostly used for food suggesting that respondents were living on 'hand-to-mouth'.

\section{Factors affecting residential location choice in the informal (waterside) settlement in Port Harcourt}

This sub-section deals with the identification of the factors which are significant in residential location decisions for informal settlers in Port Harcourt. An extensive list of factors totalling 13 which were expected to play a significant role in residential location decision was identified and used in the survey. The study presents the relative importance of each of the factors in the residential decision location of households amongst informal settlers in Port Harcourt. Table 2 and Table 3 illustrates that overall results obtained from the mean 
and relative significance index to determine relevant factors affecting households' residential location choices in the selected informal (waterfront) settlement, namely: Akokwa, Afikpo, Ibadan, Bishop Johnson, Ndoki, Etche, and Andoni waterfronts. As shown from Table 2 living close to family or friends (4.90), low rents and low

Table 2 Factors determining residential location decision of informal settlers costs of living (4.78), livelihood opportunities (4.69), proximity to work (3.82), commuting cost (3.71), distant to work $(3,71)$, nearness to children school (3.52), and personal reason (3.22) are found to be significantly related with residential location choices in waterfront settlement.

\begin{tabular}{llllllllll}
\hline \multirow{2}{*}{$\begin{array}{l}\text { Factors determining residential location } \\
\text { decision of informal settlers }\end{array}$} & \multicolumn{3}{l}{ Weights $(\mathbf{N}=\mathbf{3 1 5})$} & & & & Decisions \\
\cline { 2 - 8 } & $\mathbf{5}$ & $\mathbf{4}$ & $\mathbf{3}$ & $\mathbf{2}$ & $\mathbf{I}$ & $\mathbf{S u m}$ & Mean & \\
\hline Livelihood opportunities & 234 & 74 & 7 & 0 & 0 & 1476 & 4.69 & Significant \\
Low rents and low costs of living & 248 & 66 & 1 & 0 & 0 & 1507 & 4.78 & Significant \\
Living close to family or friends & 287 & 26 & 2 & 0 & 0 & 1545 & 4.9 & Significant \\
Nearness to Children school & 89 & 97 & 56 & 34 & 39 & 1108 & 3.52 & Significant \\
Employment availability & 47 & 33 & 55 & 104 & 76 & 816 & 2.59 & Not Significant \\
Availability of Health facilities & 45 & 23 & 77 & 114 & 56 & 832 & 2.64 & Not Significant \\
Proximity to work & 147 & 73 & 23 & 35 & 37 & 1203 & 3.82 & Significant \\
Street cleanliness & 31 & 23 & 12 & 66 & 183 & 598 & 1.9 & Not Significant \\
Commuting cost & 133 & 69 & 37 & 42 & 34 & 1170 & 3.71 & Significant \\
Personal reason & 80 & 67 & 50 & 78 & 40 & 1014 & 3.22 & Significant \\
Neighbourhood character & 23 & 43 & 55 & 111 & 83 & 757 & 2.4 & Not Significant \\
Nearness to market & 21 & 56 & 79 & 83 & 76 & 808 & 2.57 & Not Significant \\
Natural features & 33 & 39 & 31 & 87 & 125 & 713 & 2.26 & Not Significant \\
\hline
\end{tabular}

Legend: $<3.00=$ Not Significant $>3.00=$ Significant

Source: Researcher's Field Survey, 2021

Table 3 Ranking of factors determining residential location decision of informal settlers

\begin{tabular}{lllll}
\hline $\begin{array}{l}\text { Factors determining residential } \\
\text { location decision of informal settlers }\end{array}$ & Sum & Total Responses & RSI & Ranking \\
\hline Living close to family or friends & 1545 & 1575 & 0.98 & Ist \\
Low rents and low costs of living & 1507 & 1575 & 0.96 & 2 nd \\
Livelihood opportunities & 1476 & 1575 & 0.94 & 3 rd \\
Commuting cost & 1172 & 1575 & 0.74 & 4 th \\
Proximity to work & 1170 & 1575 & 0.74 & 4 th \\
Nearness to Children school & 1108 & 1575 & 0.7 & 5 th \\
Personal reason & 1014 & 1575 & 0.64 & 6 th \\
Availability of Health facilities & 832 & 1575 & 0.53 & 7 th \\
Employment availability & 816 & 1575 & 0.52 & 8 th \\
Nearness to market & 808 & 1575 & 0.51 & 9 th \\
Neighbourhood character & 757 & 1575 & 0.48 & 10th \\
Natural features & $7 \mid 3$ & 1575 & 0.45 & IIth \\
Street cleanliness & 598 & 1575 & 0.38 & 12th \\
\hline
\end{tabular}

Source: Researcher's Field Survey, 202I

However, other items like availability of health facilities, nearness to market, employment availability, neighbourhood character, street cleanliness, and natural features are not statistically significant, and as such not significant in determining residential location choices in the study area. The finding of this study justifies the need to consider the nature and values of households in the provision of appropriate dwellings for the people. 
Table 3 ranks the Factors determining residential location decision of informal settlers and shows that living close to family or friends with RSI of 0.98 , low rents and low costs of living with RSI of 0.96 , and livelihood opportunities with RSI of 0.94 , ranked higher than the other factors. This is followed by commuting cost with RSI of 0.74 , proximity to work with RSI of 0.74 , nearness to children school with RSI of 0.70 , and personal reason with RSI of 0.64 . Factors such as availability of health facilities with RSI of 0.53 , employment availability with RSI of 0.52 , nearness to market with RSI of 0.51 , neighbourhood character with RSI of 0.48 , natural features with RSI of 0.45 , street cleanliness with RSI of 0.38 which were found as not significant in determining residential location choices amongst informal settlers ranked lowest.

\section{Triangulation with expert interviews}

When these results are compared with the responses of the interviewees, there is a remarkable similarity. Among the households interviewed, result shows that living close to family and friends is one of the most significant. Interview results indicated that 11 out the 14 interviewees said their decision to live in the informal (waterfront) settlement were due to familiarity with friends and relations living in the waterfront. Also 8 of the respondent interviewees said they have been living there with their wife and children. Another 3 of the respondent said he and all his friends grew up in the waterside settlement. As stated by one of the interviewees: "I cannot live in any other neighbourhood because all my friends that grew up with me live here too. And if $i$ have any problem, I usually go to them for help".

When asked why they choose to live close to a family or friend, one of them said "I found fulfilment and happiness when I live in the midst of family or friends". Another interviewee also said "I do not feel ashamed to ask from my friends when I am financially down and they are always ready to help".

It was discovered that attraction to people from the same ethnic group and community was another reason respondents lived in same neighbourhood. One respondent explained that he chose to rent rooms in a particular tenement house because many of the co-tenants came from the same place with him. The full import of these assertions is that the expert interview feels that they could count on them for support. This position was emphasized by ${ }^{40}$ when they said "familiarity and social connections influences residential location choice and that many people are reluctant to leave familiar and convenient surrounding to which they have grown accustomed and became attached".

The interview result also confirmed that low rents and low costs of living was another factor that determines the choice of residential location in the selected waterfront. All the interviewees agreed that the reason for their choice of waterfront settlement is because the rents for single room are very low when compared with that of planned neighbourhood. One of the interviewee who resides in Akokwa waterfront confirmed this when he said:

"In the waterside here, I am paying $\$ 2000$ for a room but those living on the street are paying $\$ 6000$ for a single room, so that is why I cannot move out from the waterside because I cannot afford to pay such".

Another respondent who has lived outside an informal settlement before moving to Etche Waterfront narrates that his previous experiences in other parts of the city informed his decision to choose Etche waterside. He said: "I have lived in Borikiri and Diobu but the cost of living in those places are very high, but the cost of living in Etche waterside is very low".
Many of the respondents confirmed that people located to informal settlement for the reason that rents and cost of living are low. When respondent were asked to state their opinion on this issue, an expert interviewee who claimed he has live in Andoni waterside for more than 30 years said: "things are cheap here. I built my house from mud I dug which lowered the costs of building. The costs would have been higher in other neighbourhood that are not waterfront".

On the issue of livelihood opportunities, 9 of the respondents' interviewed said proximity to livelihood opportunities made them choose informal (waterside) settlements, 3 of them disagree while 2 of them were indifferent. Our interactions reveal that most of the households engage in a variety of informal economic activities without stress from the governmental authority. As noted by one of the interviewees in Afikpo waterside, she said: "I sell all kind of food items in a makeshift shop for many years in this waterside and my business is doing very well because there are many people living here that patronise me".

Supporting this view, another respondent who resides in Ndoki said: "I am engaged in plaiting of hair and I used my veranda for the business with no disturbance from the government authority. Also, it is relatively easier to find people who plait their hair here".

Majority of the informal settlements are adjacent to streets that are linked by road passable by commuter vehicle to the city centre. This proximity to the city centre makes it possible for the working class particularly the junior workers to reside in most of the watersides. One of the respondent household who lives in Bishop Johnson watersides and works in the state government secretariat said "I work at the state government secretariat as a cleaner. The distance between secretariat and Bishop Johnson waterside is $3.4 \mathrm{~km}$ and a round trip cost $N 100$. So I decided to rent a room because it is close to my place of work and I do trek to work when I do not have transportation fair". From the citation above, it is apparent that the households interviewed considered proximity to work, and commuting cost as reasons for the choice of informal (watersides) settlements. This finding supports ${ }^{12}$ assertion that that travel time and travel cost are significant factors in residential location. It also reiterate the work of ${ }^{14}$ that house characteristics, travel time, ease of access and public transport system contribute significantly to the location decision of residence.

Nearness to Children school was confirmed as another reason household considers when making location choices from the indebt interview. Out of the 14 interviewee households, 12 of them agreed while 2 disagreed. From our investigation, there is no primary or secondary school in the informal (watersides) settlement. Households interviewed confirmed that their children do attend primary schools located on close-by planned neighbourhood. A resident who lives in Ibadan waterside said " $m y$ children attends State School 1 primary, Ibadan street which is a walking distance from Ibadan waterside".

From these findings, it can be inferred that Location decision is not a standard behaviour governed by absolute rules, ${ }^{11}$ found residential environment, availability of amenities and opportunities, traffic and accessibility are the most determining factor ${ }^{27}$ found access to public transport, ease of cycling or walking, low levels of car traffic, and pedestrian friendliness ${ }^{28}$ found that safety and proximity to the city, public transportation; ${ }^{12}$ found travel time and travel cost $;{ }^{13}$ found house characteristics, travel time, ease of access and public transport system found safety and low traffic volume are significant factors in residential location; ${ }^{14}$ this study found social connection, low rents and low costs of living, and livelihood opportunity as the most influential determinants. 


\section{Conclusion and recommendations}

The study has explored the determinant factors that households consider when making residential location decisions in an informal (waterside) settlements. These determinants include living close to family or friends, low rents and low costs of living, livelihood opportunities, proximity to work, commuting cost, nearness to children school, and personal reason. Other factors are availability of health facilities, nearness to market, employment availability, neighbourhood character, street cleanliness, and natural features. The significance of these factors was assessed by a determination of the importance which households attach to each of the factors in the choice of residential location amongst informal settlers in Port Harcourt. The result of the survey confirms that living close to family or friends, low rents and low costs of living, livelihood opportunities, ranked higher than the other factors. This is followed by proximity to work, commuting cost, nearness to children school, and personal reason. This result was corroborated by an indebt interview conducted on 14 households across the 7 randomly selected informal (waterfront) settlements. We show that other factors such as availability of health facilities, nearness to market, employment availability, neighbourhood character, natural features, and street cleanliness were not significant in determining residential location choices amongst informal settlers. The findings of this study has further confirmed that the growing informality are not limited to income level only, but household use other resources such as social networks (living close to family or friends), livelihood opportunities, proximity to work, and commuting cost to find accommodation, land for building and support for everyday life. The paper therefore concludes that living close to family or friends, low rents and low costs of living, and livelihood opportunities, proximity to work, commuting cost, nearness to children school, and personal reason are determinants of residential location choice in an informal settlement and should be given the necessary attention by both the public and private sector in the development of urban communities. The strength of this work is the use of triangulation which uses evidence from different sources to corroborate the same fact or finding. This notwithstanding, further investigation can test this proposition using factor analysis.

\section{Acknowledgments}

None.

\section{Funding}

None.

\section{Conflicts of interest}

The authors declare that there is no conflict of interest.

\section{References}

1. United Nations Human Settlements Programme. The state of African cities 2010: governance, inequality and urban land markets. UN-HABITAT; 2010

2. Adegun OB. Shelter and the future African city. The Built \& Human Environment Review. 2011;4(2):33-40.

3. UNCHS. Urbanization: A turning point in history. Global Report on Urbanization; 2007.

4. Revi A, Satterthwaite DE, Aragon-Durand F, et al. In: Field CB, Barros VR, Dokken DJ, editors. Climate change: Impacts, adaptation, and vulnerability, part A: Global and sectoral aspects, contribution of working group II to the fifth assessment report of the intergovernmental panel on climate change. Cambridge: Cambridge University Press; 2014.
5. Nwaka GI. The urban informal sector in nigeria: towards economic development, environmental health and social harmony. Mimeo. Prague Institute for Global Urban Development. 2005.

6. Owei OB, Ikpoki M. The growth of middle and high income informal settlements in Port Harcourt, 42nd ISoCaRP Congress; 2006.

7. UN Habitat. The challenge of slums: Global report on human settlements 2003. London: Sterling, VA; 2003.

8. Durand-Lasserve A. Informal settlements and the millennium development goals: global policy debates on property ownership and security of tenure. Global Urban Dev. 2006;2(1):1-15.

9. Kironde JML. The evolution of land use structure of Dar es Salaam, 1890-1990: A study in the effects of land policy. PhD Thesis, Nairobi: University of Nairobi; 1995.

10. Payne G. Tenure and shelter in urban livelihoods. In: Rakodi C, LloydJones T, editors. Urban Livelihoods: A People Centred Approach to Reducing Poverty, London: Earthscan; 2002:154-164.

11. Schwarze B. A residential location decision support system (RLDSS) as a contribution to more sustainability in urban regions. 2010.

12. Rivera MAI, Tiglao NCC. Modelling residential location choice, workplace location and mode choice of two-worker households in Metro Manila. Proceedings of the eastern Asia society for transport studies. 2005;5:1167-1178.

13. Gayda S. Stated preference survey on residential location choice and modal choice in brussels. Paper presented at the world conference on transportation research, Antwerpen. 1998.

14. Hunt JD, McMillan DP, Abraham JEA. Stated preference investigation of influences of the attractiveness of the residential locations. Transportation research record. 1994;1466:79-87.

15. Kombe WJ, Kreibich V. Formal land management in Tanzania. Spring Research Series No. 29, Dortmund. 2000.

16. Scalar ED, Northridge ME. Editor's Choice: Slums, slum dwellers, and health. American Journal of Public Health. 2003;93(9):1381.

17. United Nations Human Settlements Programme (UN-Habitat). State of the world's cities 2012/2013: prosperity of cities. Routledge; 2013.

18. Archibong M. Port Harcourt: garden city with few flowers. The Sun Newspaper; 2004

19. Akujuru VA. Enhancing the transferability of Squatter Settlements through Title Registration: The Port Harcourt Water Fronts Experience. Nigerian Journal of Environmental Science. 2008;2:1-11.

20. Odoemene A. Agony in the Garden': Incongruity of Governance and the Travails of Port Harcourt City, Niger Delta, Nigeria, 1912-2010. Africana: The Niger Delta. 2011;1(5):108-139.

21. Obinna VC, Owei OB, Okwakpam IO. Impacts of urbanization on the indigenous enclaves of Port Harcourt and concomitant policy measures. The Social Science. 2010;5(3):172-186.

22. United Nations Department of Economic and Social Affairs (UN-ESA). World urbanization prospects: The 2014 revision. New York: The United Nations; 2014.

23. United Nations International Strategy for Disaster Reduction (UN-ISDR) Global assessment report on disaster risk reduction: revealing risk, redefining development. 2011.

24. Sanit P, Nakamura F, Tanaka S, et al. Location and mode choice decision mechanism analysis of multi-worker household in Bangkok, Thailand. Journal of the Eastern Asia Society for Transportation Studies. 2013;10:1243-1257.

25. Poku-Boansi M, Adarkwa KK. Determinants of residential location in the Adenta Municipality, Ghana. Geo Journal. 2016;81(5):779-791. 
26. Giuliani MV. Residential preferences and attachment across the lifespan. In: Spielberg C, editor. Encyclopedia of Applied Psychology. San Diego: Elsevier/Academic Press; 2004:259-266.

27. Sinniah, GK, Shah MZ, Vigar G, et al. Residential location preferences: New perspective. Transportation Research Procedia. 2016;17:369-383.

28. Wu W. Migrant Intra-urban Residential Mobility in Urban China. Housing Studies. 2006;21(5):745-765.

29. Giuliano G, Small KA. Is the journey to work explained by urban structure? Urban Studies. 1993;30(9):1485-1500.

30. Kim JH, Pagliara F, Preston J. The intention to move and residential location choice behaviour. Urban studies. 2005;42(9):1621-1636.

31. Givliamo G, Small KA. Sub centres in the Los Angeles Region. J Reg Sci UEco. 1991;21(1):163-182.

32. Hazel AM, Moon JK. Determinants of residential location decisions among the pre-elderly in central Ohio. J Trans Lan. 2009;2(1):47-67.

33. Okesoto JO, Oke GO, Olayiwola KO. Residential location preference of Lagos Central Business District working population. American Journal of Social Issues and Humanities. 2014;4(1):45-55.

34. Jin J, Lee H. Understanding residential location choices: an application of the UrbanSim residential location model on Suwon, Korea, International Journal of Urban Sciences. 2018;22(2):216-235.

35. Petkar AS, Macwan JEM, Criteria analysis of residential location preferences: An urban dwellers's perpsctive. International Journal of Urban and Civil Engineering. 2018;12(1):49-55.

36. Hensher DA. Measurement of the valiation of travel time savings. Journal of Transport Economics and Policy. 2001;35(1):71-98.

37. Meikle S. The urban context and poor people. In: Carole Rakodi, Tony Lloyd-Jones, editors. Urban Livelihoods, A people Centered Approach to Reducing Poverty. 2002.

38. Guo JY, Bhat CR. Operationalizing the concept of neighborhood: Application to residential location choice analysis'. Journal of Transport Geography. 2007;15(1):31-45.

39. Fejiten P, Hooimeijer P, Mulder CH. Residential experience and residential environment choice over the lifecourse. Urban Studies. 2008;45(1):141162.

40. Winstanley A, Thorns DC, Perkins HC. Moving house, creating home: Exploring residential mobility. Housing Studies. 2002;17(6):813-832.
41. Burgess R, Skeltys N. Findings from the housing and location choice survey: an overview. Housing and Urban Development Division \& Department of Health Housing and Community Services. Australia: Australian Government Publishing Service; 1992.

42. Acheampong RA, Anokye PA. Understanding households' residential location choice in Kumasi's peri-urban settlements and the implications for sustainable urban growth. Academic research. 2013;3(9):60-70.

43. Nkeki NF, Erimona EO. Sector-wise exploratory analysis of household residential location choice in the African context: Empirical evidence from Benin City, Nigeria. Current Urban Studies. 2018;6(01):37.

44. Anyanwu CN. The growth of Port Harcourt 1912-1960 in Ogonwo (1979), the city of Port Harcourt. A symposium on its Growth and Development. Ibadan, Nigeria: Heinemann Educational books (Nig) Ltd; 1979.

45. Rachael A. Assessing the population status of the critically endangered Niger Delta. Red Colobus (Piliococobusepiene), Primate Conservation. 2015;(29):87-96.

46. Abdul EO, Umah A, Raimi KO, et al. Waterfront regeneration in Niger Delta and its impact on waterfront settlements in Port Harcourt Metropolis (No. afres2018_105). African Real Estate Society (AfRES); 2018:399418.

47. Kio-Lawson D. The squatters of Port Harcourt, Nigeria: Their identity, wants, characteristics and Policy options. Journal of Developing countries studies. 2014;4(22):40-49.

48. Obafemi, Odubo. Waterfronts redevelopments in Port Harcourt metropolis: Issues and socio-economic implications for urban environmental management. The International Journal Of Engineering And Science (IJES). 2013;2(12);01-14.

49. Amnesty International. Port Harcourt Demolitions: Excessive use of force against demonstrators. London: Amnesty International Publications; 2010:1-17.

50. Yin RK. Case study research: Design and methods. 4th ed.. Los Angeles, CA: Sage; 2009.

51. Fellows R, Liu A. Research methods for construction. West Sussex: John Wiley \& Sons Ltd; 2008.

52. Olsen W. Triangulation in social research: Qualitative and quantitative methods can really be mixed. In: Holborn M, editor. Developments in Sociology. Ormskirk: Causeway Press; 2004.

53. Bryman A. Triangulation and measurement. 2004. 